\title{
Improving Fuel Quality of Rice Straw Through Soaking Using Wastewater from Tofu Industry
}

\author{
S Suharyatun ${ }^{1}$, A Haryanto ${ }^{1, *}$, W Rahmawati ${ }^{1}$, S Triyono $^{1}, \mathrm{U}$ Zubaidah $^{1}$ \\ ${ }^{1}$ Department of Agriculture Engineering, Agriculture Faculty, University of Lampung, Indonesia. \\ *Corresponding author. Email: agus.haryanto@fp.unila.ac.id
}

\begin{abstract}
Straw is agricultural waste that has enormous potential as an alternative energy source because of its abundant availability. However, straw has poor intrinsic properties as a fuel. Alkali metal content (especially K) is very high, causing problems in the combustion process at high temperatures. One effort to overcome this problem is by leaching to improve the quality of straw as fuel. This study aims to improve the energetic quality of rice straw through leaching. The study was conducted by soaking rice straw using tofu wastewater. Straw characteristics will be observed based on the soaking time, which is 0 (without soaking), 3.75, 7.5, 15, 30, 60, 120, and 720 minutes. The parameters measured in the study were the $\mathrm{pH}$ of tofu wastewater, ash content, potassium content, and calorific value of straw. The results showed that the leaching of minerals from rice straw by soaking for 720 minutes could improve the energetic properties of rice straw. Soaking rice straw can reduce its potassium content from $32 \%$ to $1.96 \%$ and increase its calorific value from $13.6 \mathrm{MJ} / \mathrm{kg}$ to $15.77 \mathrm{MJ} / \mathrm{kg}$.
\end{abstract}

Keywords: Rice Straw, Soaking, Tofu Waste Water, Calorific Value

\section{INTRODUCTION}

Straw is the biggest by-product in the rice production process. Each $\mathrm{kg}$ of white rice produces rice straw in the range of $0.7 \mathrm{~kg}$ and $1.4 \mathrm{~kg}$, depending on variety, cutting height, and moisture content during harvesting[1]. Rice straw production in Indonesia reaches 2.0 to 3.9 tons of dry weight (bk) per ha per harvest, or about 4.0 to 7.8 tons per ha per year[2]. Along with the development of rice production, the potential for straw in Indonesia is very large and continues to increase by around $3.1 \%$ per year[3]. Referring to the figures given by Abraham et al. (2016)[4], the potential for Indonesian rice straw in 2017 is between 81.38 million tons to 122.07 million tons.

As agricultural waste, straw can be an alternative energy source to replace fossil energy and reduce greenhouse gas emissions and avoid the problem of local pollution from open burning. Rice straw is attractive as a fuel because it can be renewed and is considered as carbon dioxide neutral[5]. Despite its abundant availability, in Indonesia straw has not been used commercially as a raw material for energy. This is because rice straw has poor intrinsic properties as fuel.
Weaknesses of straw as an energy source are low bulk density (between $80-100 \mathrm{~kg} / \mathrm{m} 3$ ), high ash content and high alkaline metal content (especially K). Low bulk density of straw causes difficulties in handling, storage and transportation. This can be overcome by densification or pelletization which can produce a homogeneous fuel with a density of 10 times thereby reducing transportation costs and storage space[6]. High levels of ash content reduce the calorific value. Straw has a low calorific value of around $13.38 \mathrm{MJ} / \mathrm{kg}$ [7] to 15.26 $\mathrm{MJ} / \mathrm{kg}$ [8]. High potassium content has the potential to cause fouling of the combustion system working at high temperature[9]. High ash and alkali metal content can cause agglomeration and slagging in boiler components [10] that will reduce system efficiency[11].Because of these limitations in rice straw fuel, efforts should be made to improve the quality of straw fuel before it is used as an energy source. This study aims to improve the energetic quality of rice straw by leaching through soaking straw using wastewater from a tofu industry. 


\section{MATERIAL AND METHODS}

\subsection{Materials}

The rice straw used in this study was taken directly from harvested rice fields. The straw is then dried in the sun to dry so that it does not rot easily during storage. The dried straw is then chopped to a length of about $1-2 \mathrm{~cm}$ and stored in a tightly zippedclear plastic bag.Tofu waste water is obtained from the household tofu industry in the Tofu Industry area in Gunung Sula, Bandar Lampung. Samples are taken before the wastewater is discharged into the sewage. Wastewater is used as is without any process as a soaking solution.

\subsection{Method}

Chopped rice straw is soaked in the tofu wastewater at a ratio of 1 part by weight of straw in 20 parts of wastewater volume. In this study 450 grams of chopped straw was used and soaked in $9.0 \mathrm{~L}$ of wastewater. The observed parameters included changes in ash content, potassium content, and $\mathrm{pH}$ of the wastewater that was used to soak the straw. Measurements were taken at various soaking times, i.e. 0 (without soaking), 3.75, 7.5, $15,30,60,120$, and 720 minutes. The calorific value of straw is compared between initial (without soaking) and that of after720 minutes soaking time.

\subsection{Analysis and Measurement}

The measurement of a fore mentioned parameters are conducted as the following:

\subsubsection{Water content (MC)}

Water content of rice straw is measured gravimetrically by drying in an oven (Memmert,type UM 500 , Germany) at $105^{\circ} \mathrm{C}$ for 24 hours. Moisture content is calculated from:

$$
\mathrm{MC}=[(\mathrm{WS}-\mathrm{DS}) / \mathrm{WS}] \times 100 \%
$$

whereWS and DS is wet solid mass (before drying) and dry solid (after drying) of rice straw, respectively.

\subsection{2 $\mathrm{pH}$}

$\mathrm{pH}$ of tofu wastewater was measured by using a portable digitalpH-meter (PHMETER, PH_009(I), China). Measurement was conducted at various soaking time as previously mentioned.

\subsubsection{Ash content.}

Ash content was measured at various soaking timeduring the leaching process. Before the ash content is measured, the sample is dried in an oven for 24 hours at $105{ }^{\circ} \mathrm{C}$. Then the dried sample $(\mathrm{Mk})$ was put into the furnace (Barnstead ThermolyneFB1300, USA) at temperature of $550{ }^{\circ} \mathrm{C}$ for 2 hours. After cooling in a desicator, the sample is weighed (Mt). Ash content is calculated by the formula:

$$
\mathrm{Ash}=(\mathrm{Mk} / \mathrm{Mt}) \times 100 \%
$$

\subsubsection{Potassium $(K)$}

Potassium content in rice straw were measured at various soaking time during the leaching process. In this case rice straw samples were send to other lab (Integrated Biomass Lab) to be analyzed using the MP-AES 4100.

\subsubsection{Calorific value.}

The calorific value of rice straw was measured using a bomb calorimeter (CAL2K). The measurement was carried out for initial straw and that of after soaking time of 720 minutes.

\section{RESULTS AND DISCUSSIONS}

Rice straw used in this experiment had a moisture content of $13 \%$ (wet basis).Results of the analysis and measurement of the study are presented in Table 1 . The level of potassium $(\mathrm{K})$ in straw decreases rapidly through immersion in tofu wastewater. Within 3.75 minutes a decrease in potassium levels reached $92 \%$, namely from 32 (\% Ash) before soaking to 2.61 (\% Ash) after soaking. Further increasein soaking time of more than 3.75 minutes does not significantly change in the decrease in $\mathrm{K}$ content. Kasim et al. (2016) reported a mineral removal of $82.4 \%$ can be achieved from empty fruit bunch soaking in $1 \%$ nitric acid for $60 \mathrm{~min}$ [12]. Rapid decrease in potassium occurs because potassium reacts with water to for potassium hydroxide as the following.

$$
2 \mathrm{~K}(\mathrm{~s})+2 \mathrm{H} 2 \mathrm{O} \rightarrow 2 \mathrm{KOH}(\mathrm{aq})+\mathrm{H} 2(\mathrm{~g})
$$

Potassium is an important metal in relation to plant nutrition as well as its effect on the combustion system. This effective reduction of potassium has double implications. On one hand, a decrease in potassium can improve fuel quality of rice atraw because it can avoid the effects of fouling on high-temperature combustion systems. On the other hand, the dissolved potassium in wastewater can be used as a source of fertilizer for plants.

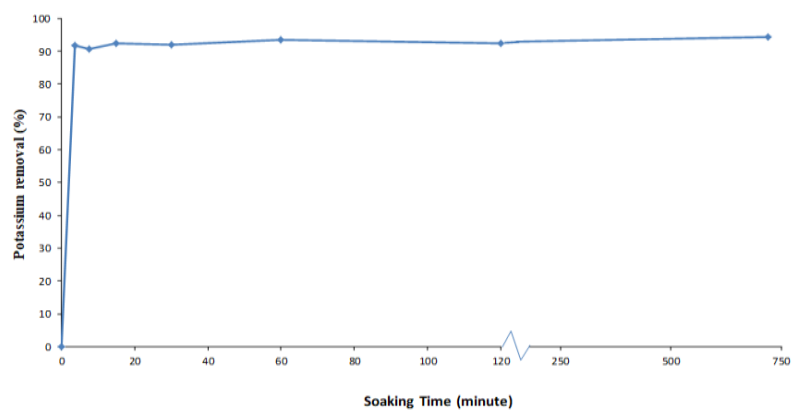


Figure1 The relation of soaking time and the decreasing effectivity of potassium content of rice straw

Table 1.The change of wastewater $\mathrm{pH}$, ash content, and potassium content

\begin{tabular}{|c|c|c|c|}
\hline $\begin{array}{c}\text { Soaking time } \\
\text { (minute) }\end{array}$ & $\begin{array}{c}\mathrm{pH} \\
\text { wastewater }\end{array}$ & $\begin{array}{c}\text { Ash content } \\
\text { (\% DS) }\end{array}$ & $\begin{array}{c}\text { K content } \\
\text { (\% Ash) }\end{array}$ \\
\hline 0 & 2.70 & 16.00 & 32.00 \\
\hline 3.75 & 3.30 & 14.80 & 2.61 \\
\hline 7.5 & 3.30 & 14.16 & 2.95 \\
\hline 15 & 3.40 & 14.97 & 2.46 \\
\hline 30 & 3.40 & 14.51 & 2.55 \\
\hline 60 & 3.50 & 13.67 & 2.11 \\
\hline 120 & 3.50 & 13.74 & 2.46 \\
\hline 720 & 3.50 & 14.82 & 1.96 \\
\hline
\end{tabular}

Table 1 also shows that the $\mathrm{pH}$ of the tofu wastewater increased with soaking time. Within 12 hours of soaking, the $\mathrm{pH}$ of wastewater rose from 2.7 to 3.5. Increasing the $\mathrm{pH}$ value of tofu wastewater is closely related to the decrease in potassium $(\mathrm{K})$ levels. Potassium is a basic metal. If dissolved will produce a solution that is alkaline. If dissolved in an acidic medium, potassium will increase the $\mathrm{pH}$ value of the solvent medium. This confirms that potassium is immediately dissolved in wastewater.

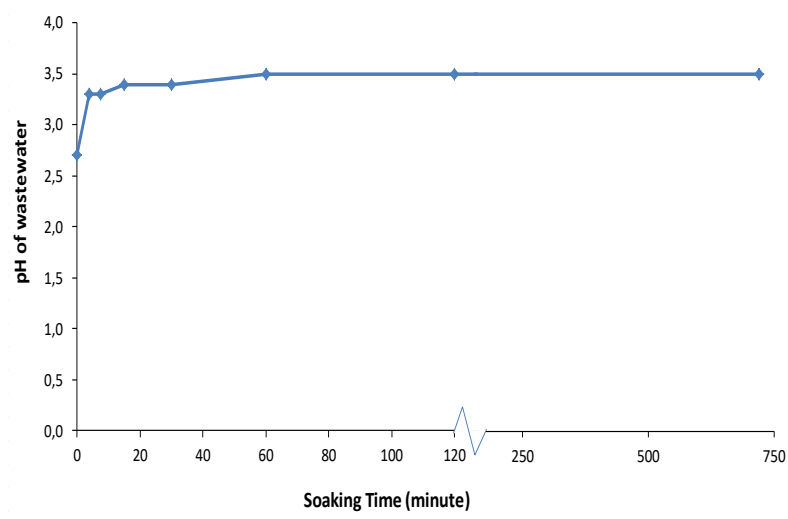

Figure 2 Effect of rice straw soaking time on the $\mathrm{pH}$ value of wastewater

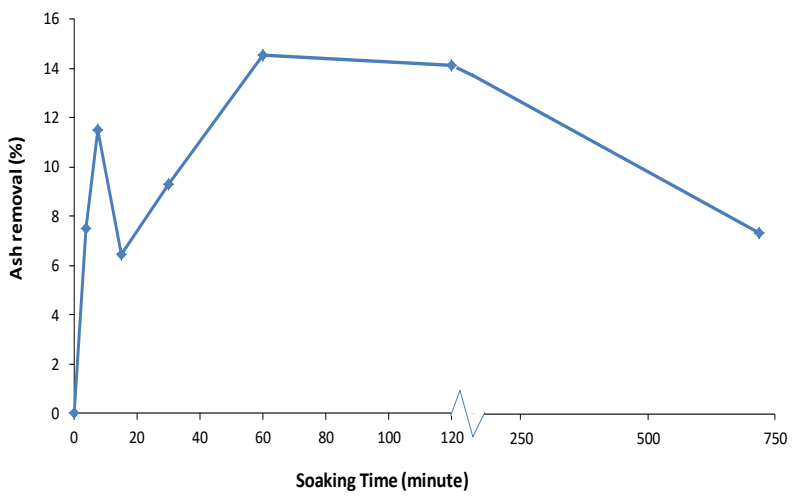

Figure 3. The relation of soaking time to the ash removal content of rice straw

Ash content in biomass is an important parameter in relation to fuel quality. High ash content results in low calorific value. Haryantoet al. (2019) [13]shows a relationship between caloric value and ash content of biomass in a linear form with $R^{2}=0.63$ (sufficient indicator of the relationship). In this study straw ash content decreased by $14.4 \%$, from initial value (without soaking) $16(\% \mathrm{DS})$ to $13.67(\% \mathrm{DS})$ after soaking for 60 minutes. This might be caused by a fact that not all minerals contained in the straw ash are soluble minerals.

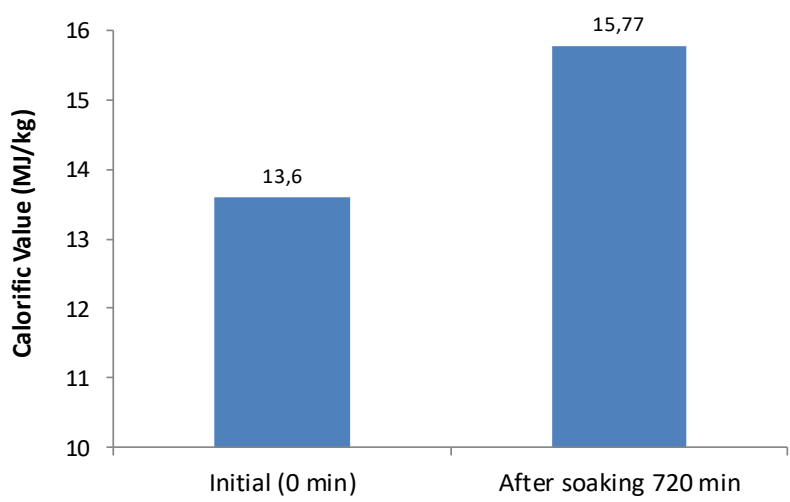

Figure 4 The increase of calorific value of rice straw due to soaking in tofu wastewater

The most important characteristic of biomass as fuel is the caloric value. High calorific value is a good indicator for biomassas fuel. Rice straw is a poor fuel because it has a low calorific value. Soaking straw in the tofu wastewater increases its heating value from 13.60 $\mathrm{MJ} / \mathrm{kg}$ (without soaking) to $15.77 \mathrm{MJ} / \mathrm{kg}$ (with a 12 hour soaking) as shown in Figure 4. This significant increasemay occur due to the decrease of ash content in the straw.

\section{CONCLUSION}

Soaking is an effective way to improve rice straw quality for fuel. Soaking rice straw using wastewater from tofu industry increases the calorific value from $16 \%$ from $13.6 \mathrm{MJ} / \mathrm{kg}$ to $15.77 \mathrm{MJ} / \mathrm{kg}$. It also decreases ash content by $14.5 \%$ from initially $16 \% \mathrm{DS}$ to $14.82 \% \mathrm{DS}$. A 
sharp $\mathrm{K}$ reduction ( $94 \%$ of the initial) from rice straw using tofu wastewater was effectively achieved within 3.75 minutes.

\section{ACKNOWLEDGMENTS}

This research was supported financially by BLU Unggulan Research Scheme, University of Lampung with contract number: 1459/UN.26.21/PN/2019.

\section{REFERENCES}

[1] IRRI (International Rice Research Institute) 2018 Rice Straw (Rice Knowledge Bank)

[2] Yasa I M R 2011 Potensi dan permasalahan jerami padi untuk pakan ternak sapi Bul. Teknol. Dan Inf. Pertan. BPTP Bali9

[3] Makhrani M 2014 Potential analysis of rice straw as an alternative energy source for substitute coal in Indonesia Appl. Mech. Mater.554 276-80

[4] Abraham A, Mathew A K, Sindhu R, Pandey A and Binod P 2016 Potential of rice straw for biorefining: An overview Bioresour. Technol.215 29-36

[5] Atchison J E 1976 Agricultural Residues and Other Nonwood Plant Fibers Science 191 768-72

[6] Tumuluru J S, Wright C T, Hess J R and Kenney K L 2011 A review of biomass densification systems to develop uniform feedstock commodities for bioenergy application Biofuels Bioprod. Biorefining 5 683-707

[7] Suramaythangkoor T and Gheewala S H 2010 Potential alternatives of heat and power technology application using rice straw in Thailand Appl. Energy87 128-33

[8] Mondal Md A H and Denich M 2010 Assessment of renewable energy resources potential for electricity generation in Bangladesh Renew. Sustain. Energy Rev. 14 2401-13

[9] Calvo L F, Gil M V, Otero M, Morán A and García A I 2012 Gasification of rice straw in a fluidized-bed gasifier for syngas application in close-coupled boiler-gasifier systems Bioresour. Technol.109 206-14

[10] Jenkins B M 1999 Biomass Engineering: Part 3.2.2. Pyrolysis Gas CIGR Handbook of Agricultural Engineering Vol. V: Energy and Biomass Engineering (United States of America: American Society of Agricultural Engineers) pp 222-48

[11] Jenkins B M, Bakker R R, Williams R B, BakkerDhaliwal R, Summers M D, Lee H, Bernheim L G, Huisman W, Yan L L, Andrade-Sanchez P and Yore M 2000 Commercial feasibility of utilizing rice straw in power generation Proceedings Bioenergy 2000 (Buffalo, New York)

[12] Kasim N N, Ismail K, Ishak M A M, Ahmad R, Mohamed A R and Nawawi W I 2016 Demineralization of oil palm empty fruit bunch (EFB) intended as a high quality bio-oil feedstock 4th IET Clean Energy and Technology Conference (CEAT 2016) 4th IET Clean Energy and Technology Conference (CEAT 2016) (Kuala Lumpur, Malaysia: Institution of Engineering and Technology) pp 107 (6 .)-107 (6 .)

[13] Haryanto A, Suharyatun S, Rahmawati W and Triyono S 2019 Energi Terbarukan dari Jerami Padi: Review Potensi dan Tantangan Bagi Indonesia J. Keteknikan Pertan. submitted 